\title{
Canadian Consensus Conference on the Management of Viral Hepatitis
}

\author{
Canadian Association for Study of the Liver (CASL) Consensus Conference Rapporteur Group
}

\begin{abstract}
Canadian Association for Study of the Liver (CASL) Consensus Conference Rapporteur Group. Canadian Consensus Conference on the Management of Viral Hepatitis. Can J Gastroenterol 2000;14(Suppl B):5B-20B. These proceedings of a consensus conference on the management of viral hepatitis were sponsored by the Canadian Association for Study of the Liver (CASL) and Health Canada. Experts in various aspects of viral hepatitis presented a review of the medical literature on assigned topics. Three expert panels were convened; they debated assigned topics, which corresponded to the reviews presented earlier. Attempts were made to reach consensus on a number of recommendations about the management of viral hepatitis. The content of the literature reviews, the debates and consensus statements were synthesized into a preliminary document. The report gives some background and offers recommendations aimed at both the general practitioner and the specialist.
\end{abstract}

Key Words: Canadian Association for Study of the Liver (CASL); Consensus conference; Hepatitis B; Hepatitis C; Hepatocellular carcinoma; Vaccination; Viral hepatitis

\section{Conférence consensuelle canadienne sur le traitement de l'hépatite virale}

RÉSUMÉ : Ce compte rendu d'une conférence consensuelle sur le traitement de l'hépatite a été rendu possible grâce à une contribution de l'Association canadienne pour l'étude du foie et de Santé Canada. Des experts de divers aspects de l'hépatite virale ont présenté une synthèse de la littérature sur des thèmes assignés. Trois comités d'experts se sont réunis; ils ont discuté des thèmes assignés correspondant au contenu de la synthèse présentée plus tôt. On a tenté d'atteindre un consensus sur certaines recommandations relatives au traitement de l'hépatite virale. Les différentes synthèses de la littérature, de même qu'un résumé des débats et des énoncés consensuels sont proposés dans un document préliminaire. Le rapport présente les données de base et formule des recommandations à l'intention de l'omnipraticien et du spécialiste.
$\mathrm{T}$ his report is the proceedings of a consensus conference on the management of viral hepatitis sponsored by the Canadian Association for Study of the Liver (CASL) and Health Canada. This meeting was open to the public. Experts in various aspects of viral hepatitis were asked to present a review of the medical literature on assigned topics. Three expert panels were convened, consisting of the speakers and other invited experts from the fields of hepatology, infectious disease, epidemiology, virology, medical microbiology and public health. The expert panels debated assigned topics, which corresponded to the reviews presented earlier. Audience participation was sought. Attempts were made to reach consensus on a number of recommendations about the management of viral hepatitis. A 'rapporteur' group (see the list of participants before the References) then synthesized the content of the literature reviews, the debates and con- sensus statements into a preliminary document. This was presented to the audience, and additional comments were sought to determine how well the document reflected the views expressed in the earlier discussions. The draft document was amended as necessary and edited to produce this report. All participants were obliged to declare publicly any potential conflicts of interest. The report gives some background and offers recommendations aimed at both the general practitioner and the specialist. The recommendations and other important statements are highlighted in the text.

\section{HEPATITIS B VIRUS}

Epidemiology of hepatitis B in Canada

The prevalence of hepatitis $B$ virus (HBV) infection varies considerably across Canada because of the heterogeneity of the Canadian population. If the Canadian population can be 
TABLE 1

Prevalence of hepatitis B virus infection in Canada

\begin{tabular}{lcc}
\hline Group & $\begin{array}{c}\text { Prevalence of } \\
\text { HBsAg+ }\end{array}$ & $\begin{array}{c}\text { Estimated number } \\
\text { of cases }\end{array}$ \\
\hline Native/Inuit & $4 \%$ & 1640 \\
Immigrant & $4.3 \%$ & 154,160 \\
Nonimmigrant & $0.2 \%$ to $0.5 \%$ & 49,862 to 124,655 \\
Total & & 206,000 to 280,000 \\
\hline
\end{tabular}

HBsAg Hepatitis B surface antigen

described by three groups - Native/Inuit, immigrant and nonimmigrant - then the estimated prevalenee and number of cases in Canada are as shown in Table 1 (1-6). Immigrants constitute the largest group of HBV carriers, particularly those from regions with high endemic rates of $\mathrm{HBV}$, such as Asia. The proportion of HBV-infected patients who are hepatitis $\mathrm{B}$ e antigen $(\mathrm{HBeAg})$-positive also varies among the different groups (1). HBeAg positivity ranges from less than $9 \%$ in the Inuit population to less than $15 \%$ for nonimmigrants to $46 \%$ for Asian immigrants and $55 \%$ for Indochinese immigrants. The majority of $\mathrm{HBeAg}$-positive cases occur in the young immigrant population.

Following acute HBV infection, the percentage of infected patients who become carriers varies with age. The risk is greatest in the very young and in the elderly (see the sections entitled 'Chronic hepatitis B in children' and 'Treatment of the hepatitis B patient').

Recommendations: Although acute hepatitis B continues to be an important clinical problem in Canada, the majority of acute cases resolve and clear hepatitis B surface antigen ( $\mathrm{HBs} \mathrm{Ag}$ ) spontaneously. Chronic HBV infection, established when HBsAg is detectable for longer than six months with or without continuing liver enzyme abnormalities, accounts for the greatest burden of disease.

\section{Natural history of chronic hepatitis B}

The course of chronic hepatitis $B$ is highly variable, characterized in some patients by exacerbations and remissions of inflammatory activity in the liver, and in others by continuous active hepatitis of varying degrees of severity, and in yet others by trivial inflammation. The disease can be divided into three phases (7). The first phase, the so-called 'immunotolerant phase', is characterized by high levels of virus in serum and no or minimal hepatic inflammation (8). These patients are HBeAg-positive. This is followed by the 'active' phase, during which there is intermittent or continuous hepatitis of varying degrees of severity (8-11). Seroconversion to anti-HBe positivity may occur during this phase (12), but cessation of inflammatory activity does not always follow. The third phase is the 'inactive' phase, during which viral concentrations are low and there is minimal inflammatory activity in the liver (13). In general, patients who clear HBeAg have a better prognosis than patients who remain $\mathrm{HBe} A g$-positive for prolonged periods (14). About $1 \%$ of anti-HBe-positive patients clear HBsAg each year (15). However, these patients remain at risk of hepatocellular carcinoma (HCC).

One of the major mechanisms by which seroconversion occurs (possibly the only mechanism) is by the development of the so-called 'precore mutant' (16). This mutation arises during the course of infection and results in inability of the virus to produce HBeAg. The virulence of this mutant is uncertain. Patients who are anti-HBe-positive with elevated atanine aminotransferase (ALT) concentrations and detectable HBV DNA almost all carry the precore mutant. However, anti-HBe-positive patients with normal ALT levels and undetectable HBV DNA also frequently carry the mutant. Virulence may be determined by another related mutation in precore mutants.

Patients with hepatitis B-induced cirrhosis who are antiHBe-positive have a $97 \%$ five-year survival rate compared with a $72 \%$ survival rate for those who are HBeAg-positive (17). Once hepatic decompensation occurs in anti-HBepositive patients, the survival at five years is only $28 \%$, whereas in $\mathrm{HBeAg}$-positive patients the four-year survival rate is zero (18). Factors predicting an adverse outcome include active hepatitis, bridging necrosis on biopsy, older age and persistent HBV DNA in serum (19).

Patients with chronic hepatitis $\mathrm{B}$ are at risk of developing HCC (20). The relative risk has been prospectively determined to be about 100, but that is highly dependent on the population being examined. Studies in Asian populations describe a much higher risk than Caucasian populations. However, even in a Caucasian population, the 10-year incidence of HCC may be as high as 15\% (17).

\section{Evaluation of the $\mathrm{HBsAg}$-positive patient}

Who should be tested? Any patient with clinical or laboratory evidence for either acute or chronic liver disease should be considered as possibly infected with HBV. Individuals engaged in high risk activities, such as intravenous drug use or high risk sexual practices, are at risk, as well as individuals exposed to blood by reason of their occupation. In addition, being a member of a population with a high endemic rate of $\mathrm{HBV}$ is a risk factor for infection. HBV infection is diagnosed based on the detection of HBsAg in serum. All HBsAg-positive individuals require further detailled assessment. The objectives are to characterize the nature of the infection, and the extent and severity of any underlying liver disease. Other objectives include identifying patients who may benefit from antiviral treatment, early diagnosis and management of cirrhosis and it complications, timely detection of HBV-associated HCC and immunization of contacts at risk.

Recommendation: Any patient with clinical or laboratory evidence of either acute or chronic liver disease should be considered to be possibly infected with HBV. 
TABLE 2

Initial investigation of the hepatitis B carrier

\begin{tabular}{lc}
\hline Test & Item(s) tested \\
\hline Liver inflammation & AST, ALT \\
Liver function tests & Bilirubin, prothrombin time/INR, albumin \\
Viral serology & $\mathrm{HBeAg} /$ anti-HBe, Anti-HCV \\
Other & $\mathrm{BUN}$ or creatinine \\
& $\mathrm{CBC}$ and differential \\
\hline
\end{tabular}

ALT Alanine aminotransferase; AST Aspartate aminotransferase; BUN Blood urea nitrogen; $C B C$ Complete blood count; $\mathrm{HBeAg}$ Hepatitis B e antigen HCV Hepatitis C virus; INR International normalized ratio

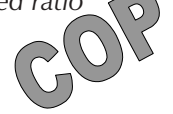

Chronic hepatitis B - Initial investigations: The laboratory tests needed in the initial assessment in all cases of chronic HBV infection are listed in Table 2. Measurement of the aminotransferase levels provides a measure of ongoing inflammation, whereas the bilirubin level, albumin level and international normalized ratio (INR) estimate liver function. Anemia, leukopenia or thrombocytopenia may indicate cirrhosis with portal hypertension. A positive HBeAg is associated with the continued presence of actively replicating $\mathrm{HBV}$ in the liver and detectable HBV DNA in the blood. Such patients are at risk of ongoing liver injury. Their blood and body fluids are highly infectious. Anti-HBepositive patients may have much lower viral loads, which may be undetectable in blood by standard assays. These patients usually have little ongoing liver damage. Anti-HBepositive patients may be infected with the so-called precore mutant, which does not produce $\mathrm{HBeAg}$. These patients may have detectable HBV DNA and may develop progressive liver disease leading to cirrhosis and, therefore, merit lifelong observation. In selected cases, additional tests are needed. Anti-HCV should be requested in patients at high risk (those with history of intravenous drug use, high risk sexual exposures, origin in countries of high $\mathrm{HCV}$ prevalence). For those at risk of HCC (long term and childhood infections, positive family history) and those in whom cirrhosis is suspected, an ultrasound is strongly advised.

Chronic hepatitis B - Special investigations - HBV DNA assays: HBV DNA can be detected in serum by several commercially available methods; Table 3 lists the current tests, along with their limits and ranges. There is poor interassay standardization, so quantification of HBV DNA when tested on different assays can vary by approximately 10 -fold or more when testing the same specimen. There is also considerable intra-assay variation, meaning that repeat testing of the same sample results in a significant difference in results (coefficient of variation for branched chain DNA [bDNA] assay is $10 \%$ to $20 \%$, and for polymerase chain reaction [PCR] assays is $20 \%$ to $40 \%$ ). It is, therefore, important for the clinician to understand the type of assay methodology used and its limitations, and that a consistent methodology be used for all assays. HBV DNA testing should be limited to patients being considered for treatment and for evaluating treatment response. It is not indicated routinely in the
TABLE 3

Manufacturers' reported dynamic ranges for hepatitis B virus (HBV) DNA assays

\begin{tabular}{lc}
\hline Method & Working range \\
\hline Abbott Solution Hybridization Assay & 1.6 to $\sim 800 \mathrm{pg} / \mathrm{mL}$ \\
Digene First Generation Hybrid & 5 to $2000 \mathrm{pg} / \mathrm{mL}$ \\
Capture Assay & $\left(1.4 \times 10^{6}\right.$ to $\left.5.6 \times 10^{8} \mathrm{Copies} / \mathrm{mL}\right)$ \\
Digene Second Generation Hybrid & \\
Capture Assay & \\
Standard test & $1.4 \times 10^{5}$ to $1.7 \times 10^{9} \mathrm{copies} / \mathrm{mL}$ \\
Ultrasensitive method & $4.7 \times 10^{3}$ to $5.6 \times 10^{7} \mathrm{copies} / \mathrm{mL}$ \\
Chiron Quantiplex bDNA Assay & 0.7 to $5000 \mathrm{mEq} / \mathrm{mL}$ \\
Roche Amplicor HBV Monitor PCR & $\left(7 \times 10^{5}\right.$ to $\left.5 \times 10^{9} \mathrm{copies} / \mathrm{mL}\right)$ \\
Assay & 1000 to $1 \times 10^{7} \mathrm{copies} / \mathrm{mL}$ \\
\end{tabular}

bDNA Branched chain DNA; PCR Polymerase chain reaction

evaluation of all HBsAg-positive patients. HBV DNA testing should be readily available to qualified practitioners regularly involved in HBV treatment.

Recommendations: It is important for the clinician to understand the type of assay methodology used and its limitations, and that a consistent methodology be used for all assays.

HBV DNA testing should be limited to patients being considered for treatment and for evaluating response to treatment. It is not indicated routinely in the evaluation of all HBsAg-positive patients. HBV DNA testing should be readily available to qualified practitioners regularly involved in the treatment of HBV.

Liver biopsy: Biochemical or serological tests, including HBV DNA, cannot predict histopathology with adequate precision. Therefore, liver biopsy may be required to determine the severity of permanent liver injury (fibrosis or cirrhosis). The biopsy results may help in choosing appropriate therapy.

Ancillary tests: The detection of immunoglobulin $\mathrm{M}$ antihepatitis $\mathrm{B}$ core antigen $(\mathrm{HBcAg})$ in the serum is not a reliable surrogate for HBV DNA testing. Its use is not recommended for this purpose. Positive immunostaining of hepatocyte nuclei and cytoplasm for HBcAgreliably predicts the presence of HBV DNA in serum.

Treatment of the hepatitis $B$ patient: The licensing of the nucleoside analogue lamivudine has significantly increased the therapeutic options available to manage HBV-infected patients. Clinical trials indicate that the response rates (as measured by HBeAg seroconversion to anti-HBe-positive) after lamivudine therapy in $\mathrm{HBeAg}$-positive patients with elevated liver enzymes range from $17 \%$ to $33 \%$, and are comparable with seroconversion rates documented with interferon (IFN) therapy (21-23). Loss of $\mathrm{HBsAg}$ with lamivudine therapy occurs in fewer than $5 \%$ of patients, compared with a rate of $8 \%$ to $33 \%$ in those treated with IFN 
(23). Response to lamivudine therapy is associated with improved liver histology. Preliminary results suggest that combined therapy with IFN and lamivudine has no advantage over the use of either IFN or lamivudine alone. Lamivudine is well tolerated with minimal side effects. Its use is associated with the development of viral mutants, the so-called 'YMDD mutants' (24), which may develop in 16\% to $32 \%$ of treated patients after one year of therapy $(21,22)$. Although these mutants often appear to be less virulent than the wild type HBV, they have been associated with rapidly progressive liver disease in some patients.

There are no data on the long term benefits of lamivudine therapy. The initial trigger for consideration of treatment is an abnormal ALT level, defined as an elevated ALT on at least three consecutive occasions over three months. For IFN therapy, the cutoff is twice the upper limit of normal, and for lamivudine therapy, 1.3 times the upper limit of normal. A response to therapy is defined as loss of $\mathrm{HBeAg}$, development of anti-HBe, clearance of HBV DNA from serum (by the bDNA, solution hybridization or hybrid capture assays) and normalization of the aminotransferase levels. This response is seen when IFN treatment stops or by three to six months after IFN therapy ends, whereas on lamivudine therapy, such a response is usually seen while the patients is still being treated.

The recommendations below apply only to patients older than 18 years of age (see the section entitled 'Chronic hepatitis B in children').

In the HBeAg-positive patient with abnormal ALT levels, liver biopsy is strongly recommended but not mandatory. Treatment is recommended regardless of the stage of fibrosis. However, the degree of fibrosis may influence the choice of therapy. Therapy may be either IFN or lamivudine. The dosage of IFN is 27 to $35 \mathrm{MU}$ weekly ( 5 to $6 \mathrm{MU} /$ day or 9 to $10 \mathrm{MU}$ three times/week [TIW]) for 16 weeks (25-32). Lamivudine is given at a dose of $100 \mathrm{mg} /$ day for 52 weeks (21). Factors that should be considered in choosing an appropriate regimen include patient age, pretreatment liver histology (amount of fibrosis), HBV viral load and the potential side effects of the drugs (33). Other important considerations are the risk of developing mutant viruses and the implications for future antiviral therapy, and the likelihood of pregnancy. IFN therapy results in a delayed but enhanced clearance of HBsAg compared with clearance in untreated patients. Treated patients have a five-year rate of $\mathrm{HBs}$ Ag clearance of $16 \%$ versus $4 \%$ in the untreated group (15). The data on the efficacy of lamivudine on HBsAg clearance are not available.

In patients treated with IFN, development of anti-HBe with normalization of ALT is a good surrogate marker for HBV DNA clearance. Therefore, monitoring with HBV DNA is not essential. In patients treated with lamivudine, clearance of HBV DNA is a marker of treatment efficacy. The ALT response may be delayed or incomplete. Thus, HBV DNA testing is essential to evaluate the response to therapy. In addition, an increase in ALT levels while on treatment may be a marker of the development of viral resis- tance to lamivudine, and should be followed by quantitative assessment of hepatitis B viral DNA levels.

In anti-HBe-positive patients with elevated ALT levels and detectable HBV DNA (precore mutant), therapy is more difficult. These patients do not respond well to IFN $(33,34)$. There are reports of sustained viral clearance with extended IFN treatment (six to 12 months). However, these data remain controversial. While lamivudine treatment suppresses viralreplication in these patients and improves levels of ALT (35), the relapse rate is high once treatment is stopped. The consensus was that these patients should be treated in expert centres.

Lamivudine therapy for patients who are anti-HBepositive and HBV DNA-positive is still considered experimental. The use of prednisone withdrawal before IFN therapy is contraindicated in the management of HBVassociated disease. IFN use in the immunosuppressed patient is not effective. In the setting of organ transplantation, upregulation of human leukocyte antigen display may also enhance rejection.

The optimal management of $\mathrm{HBV}$-infected patients who are immunosuppressed has not yet been defined. These patients include those who have received a transplanted organ other than the liver, or who are being treated for autoimmune disease or malignancy. Routine screening of patients undergoing organ transplantation is standard practice. There is insufficient information to support routine screening of other immunosuppressed patients for HBV infection. However, patients with risk factors should be screened. There is also insufficient information to recommend lamivudine antiviral prophylaxis for immunosuppressed patients who are known to be hepatitis B carriers. There are several case reports of lamivudine use in patients following renal transplantation and bone marrow transplantation; results indicate that suppression of virus is possible, with resolution of the hepatitis $(36,37)$. However, there are no reports of long term outcome; therefore, no recommendations can be made for or against the use of lamivudine in immunosuppressed patients. 
Recommendations: In the HBeAg-positive patient with abnormal ALT levels, liver biopsy is strongly recommended, but not mandatory.

Therapy may be with either IFN or lamivudine. IFN is given at a dose of 27 to $35 \mathrm{MU}$ weekly (5 to $6 \mathrm{MU} /$ day or 9 to $10 \mathrm{MU}$ TIW) for 16 weeks. Lamivudine is given at a dosage of $100 \mathrm{mg} /$ day for 52 weeks. Lamivudine therapy for patients who are anti-HBe-positive and HBV DNA-positive is still considered experimental. Prednisone withdrawal before IFN therapy is contraindicated in the management of HBV-associated disease. There is insufficient information to recommend routine screening of immunosuppressed patients for HBV infection. There is also insufficient information to recommend lamivudine antiviral prophylaxis for immunosuppressed patients who are known to be hepatitis B carriers.

\section{Special cases}

Hepatitis D virus: Hepatitis D virus (HDV) is a small, defective RNA virus that requires the presence of a coating of $\mathrm{HBs} A g$ for entry into and exit from the hepatocyte. HDV, therefore, may be acquired as a co-infection simultaneously with hepatitis B or as a superinfection in a patient who already is a carrier of HBV. Infection with hepatitis D usually causes an aggressive hepatitis (38). IFN at a dosage of $9 \mathrm{MU}$ TIW for a year can induce a virological response, but this is only sustained in $21 \%$ of cases when assessed six months after completing therapy (39). Whether IFN therapy alters outcome in terms of morbidity or mortality is unknown. $\mathrm{Pa}$ tients with active hepatitis $\mathrm{D}$ should be treated in expert centres.

Recommendation: Patients with active hepatitis D should be treated in expert centres.

Decompensated hepatitis B cirrhosis: Patients with decompensated HBV-associated liver disease have a poor prognosis, particularly those with active viral replication. Low dose IFN therapy in such patients (HBeAg-positive) may result in one-third of patients responding with seroconversion and improvement in liver function. Some $20 \%$ to $70 \%$ of patients, however, have significant complications from the treatment (40). Lamivudine appears to yield a better response rate, approaching $80 \%$, without significant side effects (personal communication). Whether results from using lamivudine change the overall outcome remains to be determined.

Patients with decompensated chronic hepatitis B are candidates for liver transplantation. Before the availability of antiviral therapy, reinfection of the graft was common. Chronic hepatitis B after liver transplantation causes aggressive disease and a rapid evolution to cirrhosis and liver failure. Many liver transplantation centres are treating these patients with lamivudine before transplantation. Some patients may improve sufficiently to avoid or delay the need for organ transplantation.

Timing of the introduction of lamivudine is important. Waiting times for liver transplantation are long. Prolonged use of lamivudine pretransplant may allow the appearance of the YMDD variant. Patients with this YMDD variant develop HBV DNA in serum once more, and may lose their opportunity for transplantation. Therefore, the possibility of 5 improved liven function must be balanced by the risk of emergent viral resistance. Furthermore, some patients in transplant studies experience a return of active hepatitis after developing YMDD-variant HBV and may progress to Piver failure and death. Loss or partial loss of lamivudine virological efficiency in patients with advanced disease, immunosuppression or both may also be associated with more frequent or more severe disease progression than that observed in nondecompensated patients.

Low dose IFN is not recommended in patients with decompensated hepatitis B cirrhosis. They should be referred to a liver transplantation centre, and treatment with lamivudine coordinated with the transplantation centre.

Recommendations: Low dose IFN is not recommended in decompensated hepatitis B cirrhosis. Patients with decompensated chronic hepatitis B should be referred to a liver transplantation centre, and treatment with lamivudine should be coordinated with the transplant centre.

Extrahepatic manifestations of hepatitis B - Glomerulonephritis: Both acute and chronic HBV infections have been associated with membranoproliferative glomerulonephritis, in which immune complexes are deposited in the basement membrane of the glomerulus. IFN therapy is very effective for hepatitis B-induced membranous glomerulonephritis, but response is poor in those with membranoproliferative glomerulonephritis $(41,42)$. In membranoproliferative glomerulonephritis, $\mathrm{HBeAg}$ clearance occurs in the same proportion of patients as with standard indications for chronic liver hepatitis B. Corticosteroid therapy is contraindicated. There are no reports on the use of lamivudine in these patients. The indications for IFN therapy in patients with hepatitis B-induced membranoproliferative glomerulonephritis are the same as for hepatitis B patients without glomerulonephritis, that is, the indication for treatment is liver disease. In membranous glomerulonephritis, the renal disease is an indication for IFN therapy because the response rate is so good. No recommendations for or against the use of lamivudine can be made. 
TABLE 4 Early childhood hepatitis B virus infection: Risk of chronicity

\begin{tabular}{lc}
\hline Age at infection (years) & Proportion who become carriers (\%) \\
\hline$<1$ & $70-90$ \\
$2-3$ & $40-70$ \\
$4-6$ & $10-40$ \\
$>7$ & $6-10$ \\
\hline
\end{tabular}

Recommendations: The indications for TFN therapy in patients with hepatitis B-induced membranoproliferative glomerulonephritis are the same as for hepatitis B patients without glomerulonephritis. In membranous glomerulonephritis, the renal disease per se is an indication for IFN therapy. No recommendations for or against the use of lamivudine could be made.

Chronic hepatitis B in children: The risk of chronicity in hepatitis B infections in newborns and early childhood is high (see Table 4). In addition, most infants and young children infected with hepatitis B have normal aminotransferase levels and are not candidates for therapy $(8,43)$. Children who are first infected at older than seven years of age have a low risk of developing chronic disease. The prognosis of hepatitis B in children is generally good. Cirrhosis and HCC are only rarely seen in childhood. Spontaneous seroconversion from $\mathrm{HBeAg}$ to anti-HBe antibody occurs in $6 \%$ to $12 \%$ of infected children per year. In randomized, controlled trials, treatment with IFN in children resulted in 35\% clearance of HBV DNA and HBeAg (11\% in controls), and in 7\% clearance of HBsAg ( $1 \%$ in controls) (44). Optimal treatment is between 3 and $6 \mathrm{MU} / \mathrm{m}^{2}$ of IFN TIW for six months. The indications for treatment are similar to those in adults.

There is no information on the use of lamivudine in children. Normally treatment should not begin before two years of age because of the side effects of IFN . In older children, the side effects of IFN appear to be well tolerated. Weight loss can be offset by dietary interventions.

Comment: The treatment of chronic hepatitis B is complex and evolving rapidly. Only physicians who are familiar with the disease and its management should undertake the treatment of chronic hepatitis B. Appropriate therapy may require consultation with experts because inappropriate therapy may limit future therapeutic options.

Recommendations: Optimal treatment is between 3 and $6 \mathrm{MU} / \mathrm{m}^{2}$ IFN TIW for six months. Indications for treatment in children are similar to those in adults.

\section{HEPATITIS C VIRUS}

Hepatitis $\mathrm{C}$ virus (HCV) is a heterogeneous, singlestranded, positive-sense RNA virus belonging to the
Flaviviridae family. Like many other RNA viruses, HCV has an inherently high mutation rate. This results in considerable genetic heterogeneity throughout the genome, essentially subdividing $\mathrm{HCV}$ into six major genotypes that vary in distribution worldwide (45). Genotype 1 appears to be the predominant type in Canada (46-49). Quasispecies are closely related variants of a single genotype within a single individual that arise from mutations that occur during viral replication Quasispecies diversity may increase with time and contribute to IFN resistance and viral persistence. Information on the rates of chronicity development after an initial HCV infection comes largely from studies of post-transfusion hepatitis. In these studies, viral clearance from serum occurred in about $20 \%$ to $30 \%$ of patients initially infected with hepatitis C. It is not known whether this viral clearance from serum is also true for hepatitis $\mathrm{C}$ acquired through other routes. To be confident that viral clearance has been achieved, PCR-based assays must be used. Negative HCV RNA by PCR assays indicates viral clearance from serum, but gives no information about the state of $\mathrm{HCV}$ in the liver or in other privileged niches (eg, lymphocytes). Thus, complete viral clearance cannot be ascertained with certainty. Therefore, patients who are anti-HCV-positive who have spontaneously developed negative HCV RNA by PCR should continue to be monitored at intervals for the presence of liver disease.

The outcome of chronic HCV infection is not well defined. A proportion of patients ultimately develop cirrhosis and HCC (50-52). However, the proportion of patients at risk of this outcome has not been accurately determined. Various reports have suggested that the lifetime risk of cirrhosis in HCV carriers is between 20\% and 50\%. Although several factors that increase this risk have been identified, for example, alcohol consumption (53-55), the magnitude of the increase in risk has not been well defined. Furthermore, the rate at which disease progresses has also not been completely defined (56-58). Some studies have indicated that after 17 years of infection, the prevalence of cirrhosis is no more than 2\% (59). Other studies have indicated that the mean duration between infection and the first diagnosis of cirrhosis is about 20 years (50). The differences in these studies are accounted for by referral bias. As a result, there is considerable uncertainty about the rate of disease progression. Factors that increase the risk of progression to cirrhosis include age over 40 years, consumption of even moderate amounts of alcohol (53-55) and increased age at acquisition of infection.

Patients infected by transfusion are also thought to have more aggressive disease, but in this cohort, having a transfusion may be a surrogate marker for increased age at disease acquisition, because the transfused population is considerably older than the average population. The risk of progression to cirrhosis also appears to be related to the degree of liver inflammation and fibrosis seen at biopsy. Patients with persistently normal ALT levels have a lower likelihood of progression to cirrhosis $(56,60,61)$. There is no clear association of disease progression with genotype or viral load. 
Co-infection with human immunodeficiency virus (HIV) is associated with higher viral loads and a more rapid progression to cirrhosis (see 'Hepatitis C and HIV'). Co-infection with hepatitis $\mathrm{B}$ is associated with a greater risk of HCC than either disease alone (see 'Screening patients with chronic hepatitis B and hepatitis C for HCC', below). Predictions of disease progression depend on the assumption that the rate of disease progression is linear and that it takes an equal amount of time to progress from, for instance, stage 1 to stage 2 fibrosis as from stage 3 to stage 4 . This assumption may not be correct.

Once cirrhosis has developed, the 10 -year survival is about $80 \%$. However, the complication rate from cirrhosis over the same time period is about $40 \%$ (62). Over the next 10 to 20 years, chronic hepatitis $\mathrm{C}(\mathrm{CHC})$ is predicted to be come a major burden on the health care system in Canada because patients who are currently asymptomatic with relatively mild disease will progress to end-stage liver disease and develop HCC. Predictions in the United States indicate that there will be a $60 \%$ increase in the incidence of cirrhosis, a $68 \%$ increase in hepatoma incidence, a $279 \%$ increment in the incidence of hepatic decompensation, a $528 \%$ increase in the need for transplantation and a $223 \%$ increase in liver death rate. There are no comparable studies to assess the future health burden in Canada, but because the demographics in the United States and Canada are similar, a similar increase in these disease states can be expected in Canada.

Recommendations: Patients who are anti-HCV positive who spontaneously develop negative $\mathrm{HCV}$ RNA by PCR should continue to be monitored at intervals for the presence of liver disease.

Factors that increase the risk of progression to cirrhosis include age over 40 years, consumption of even moderate amounts of alcohol and increased age of acquisition of infection.

The risk of progression to cirrhosis also appears to be related to the degree of liver inflammation and fibrosis seen at biopsy. Patients with persistently normal ALT levels have a lower likelihood of progression to cirrhosis.

Hepatitis C RNA testing: As with HBV DNA testing, there is a large inter- and intra-assay variation with $\mathrm{HCV}$ RNA testing. Once more, the requesting physician should be familiar with the characteristics of the assay being used (Table 5), and the use of a particular assay should be consistent. This variability must be considered when adapting results from the published literature to local practice.

There are two types of assay for hepatitis C viral RNA. Qualitative tests give a positive or negative result. Quantitative tests give the viral concentration or viral load.

The only qualitative assay available is the Roche Amplicor assay (Basel, Switzerland) (lower limit of sensitivity 100 copies $/ \mathrm{mL}$ ). Quantitative assays available include the Chiron bDNA assay (Emeryville, California) and the Roche
TABLE 5

Manufacturers' reported dynamic ranges for hepatitis $C$ virus (HCV) RNA assays

\begin{tabular}{lc}
\hline Method & Working range \\
\hline $\begin{array}{l}\text { Roche AMPLICOR HCV Monitor } \\
\text { (Quantitative) PCR Assay }\end{array}$ & $1-2 \times 10^{3}$ to $5 \times 10^{7} \mathrm{copies} / \mathrm{mL}$ \\
Roche AMPLICOR HCV & $100 \mathrm{copies} / \mathrm{mL}$ \\
(Qualitative) PCR test & (lower limit of sensitivity) \\
Chiron Quantiplex bDNA & 0.2 to $120 \mathrm{mEq} / \mathrm{mL}$ \\
HCV RNA Assay version 2 & $\left(2 \times 10^{5}\right.$ to $1.2 \times 10^{9} \mathrm{copies} / \mathrm{mL}$ ) \\
NGI (National Genetics Institute) & 100 to $5.0 \times 10^{7}$ copies $/ \mathrm{mL}$ \\
HCV SuperQuant & \\
\hline
\end{tabular}

DDNA Branched chain DNA; PCR Polymerase chain reaction

TABLE 6

Interpretation of hepatitis C virus (HCV) RNA testing in anti-HCV-positive patients

\begin{tabular}{lcl}
\hline $\begin{array}{l}\text { ALT } \\
\text { concentration }\end{array}$ & $\begin{array}{c}\text { HCV RNA } \\
\text { result }\end{array}$ & \multicolumn{1}{c}{ Interpretation } \\
\hline Normal & Positive & $\begin{array}{l}\text { Patient is infected, with undetectable } \\
\text { liver disease } \\
\text { Formal }\end{array}$ \\
Negative & $\begin{array}{l}\text { False-positive anti-HCV } \\
\text { Spontaneous viral clearance } \\
\text { False negative HCV RNA } \\
\text { Dormant infection with no or minimal } \\
\text { liver disease }\end{array}$ \\
Elevated & Positive & $\begin{array}{l}\text { Infected with active liver disease } \\
\text { Elevated }\end{array}$ \\
Negative & $\begin{array}{l}\text { False positive } \\
\text { Spontaneous viral clearance } \\
\text { False negative HCV RNA } \\
\text { Dormant hepatitis C infection, but } \\
\text { some other cause of liver disease }\end{array}$ \\
\hline
\end{tabular}

ALT Alanine aminotransferase

Monitor assay, which measures down to 1000 particles $/ \mathrm{mL}$. The most recent studies on therapy using IFN and ribavirin or PEGylated IFN use the National Genetics Institute (NGI) HCV SuperQuant assay (NGI; Culver City, California), which, although commercially available, requires the sample to be sent to the NGI laboratory. There is approximately a 10 -fold difference between the Monitor and the SuperQuant assay, so that $2 \times 10^{6}$ copies $/ \mathrm{mL}$ in the SuperQuant assay is equivalent to about $2 \times 10^{5}$ copies $/ \mathrm{mL}$ in the Monitor assay. This becomes important when comparing viral load data between published studies and individual patients.

\section{Use of HCV RNA testing}

Qualitative HCV RNA testing is not essential to the diagnosis of hepatitis $\mathrm{C}$ in typical patients who are anti-HCV positive. HCV RNA testing is indicated in patients who are anti-HCV-positive with normal ALT levels. Interpretation of the results of such testing is given in Table 6. HCV RNA testing is also sometimes necessary in patients who are immunosuppressed and have unexplained elevations of aminotransferase levels. In these patients, there may be a false negative anti-HCV assay. Qualitative HCV RNA may also 
be used to determine whether infants of infected mothers are also infected (see the 'Mother-to-infant HCV transmission' section) and to resolve indeterminate serological testing. Qualitative HCV RNA monitoring is also useful in assessing the response to therapy.

Quantitative HCV RNA testing is not routinely required for all patients. There was no consensus as to the requirement for quantitative HCV RNA testing before treatment. Viral load is a predictor of therapy response, but the panel felt that viral load should not be used to assess duration of therapy (see 'Dose and duration of treatment', below). High viral loads should not be a deterrent to initiating treatment.

Recommendations: Qualitative HCV RNA testing is not essential to diagnose hepatitis $\mathrm{C}$ in typical patients who are anti-HCV positive. Quantitative HCV RNA testing is not routinely required for all patients.

\section{Sexual transmission of $\mathrm{HCV}$}

Direct percutaneous inoculation is the most efficient mode of transmitting HCV, although sexual, household occupational and vertical transmission of $\mathrm{HCV}$ may also occur (63-67). HCV intraspousal transmission appears to be rare in the absence of a parenteral risk in the partner. In case control studies, sexual cohabitation with an anti-HCV-positive person was not identified as a risk of infection. Therefore, $\mathrm{HCV}$ is not considered to be a sexually transmitted disease. Some factors, however, such as sexual promiscuity, HIV and herpes simplex virus 2 co-infections, are associated with sexual transmission of hepatitis C $(66,67)$. It is not clear whether the probability of transmission between partners increases with decades of marriage and/or age $(68,69)$. Transmission of HCV does not necessarily represent sexual transmission.

The infected person should inform sexual partners. Testing should be offered to the sexual partner. Patients should be advised to avoid sharing items of personal hygiene. In short term sexual relationships, condom use is advised. Unprotected sex during menstruation should be avoided. Couples should be given information about the risks of transmission and about precautions that may reduce the risk of transmission. The committee neither recommends nor recommends against the use of condoms in stable monogamous relationships. It is up to the couple to make a decision, based upon the best information that can be provided to them.
Recommendations: HCV intraspousal transmission appears to be rare in the absence of a parenteral risk in the partner.

The infected person should inform sexual partners. Testing should be offered to sexual partners. Patients should be advised to avoid sharing items of personal bygiene. In short term sexual relationships condom use is advised. Unprotected sex during menstruation should be avoided. Couples should be given information about the risks of transmission, and about precautions that may reduce the risk of transmission in stable monogamous relationships. The committee makes no recommendation for or against the use of condoms. The choice belongs to the couple.

\section{Mother-to-infant $\mathrm{HCV}$ transmission}

Rates of transmission of hepatitis $\mathrm{C}$ from mother to newborn infant vary between $0 \%$ and $3 \%(70-73)$. Two risk factors have been identified: HIV infection in the mother and high maternal viral load $(70,73)$. It is controversial whether caesarian section prevents transmission of HCV. Results of testing breast milk for HCV RNA are conflicting. However, transmission from breast milk has not been documented. Breastfeeding is considered safe and is not contraindicated.

Anti-HCV testing in the neonate is not helpful because there is passive transfer of antibody across the placenta. This may take 12 to 18 months to clear. Testing for hepatitis $\mathrm{C}$ infection within the first 18 months of life should be by PCR assays.

There is very limited information in the literature concerning the rate of chronicity after neonatal transmission. Clearance of the virus may occur more frequently than in adult infection.

Recommendations: Rates of transmission of hepatitis C from mother to newborn infant vary between $0 \%$ and $3 \%$ according to different reports.

Breastfeeding is considered safe and is not contraindicated. Testing for hepatitis $\mathrm{C}$ infection within the first 18 months of life should be done via PCR assays.

\section{Therapy for $\mathrm{CHC}$}

The prime indication for treatment in CHC is an ALT level more than 1.5 times the upper limit of normal on three consecutive occasions over more than three months. Patients with ALT levels below that level usually have mild disease and an excellent prognosis (60). Treatment may not be required. IFN monotherapy treatment in this group is largely ineffective. There are no data on the use of IFN and ribavirin combination therapy in this group. Although ALT is the trigger for considering treatment, other factors may also influence the decision whether to treat.

A liver biopsy is recommended for grading and staging of the liver disease. When treating immunosuppressed patients, such as renal or bone marrow transplant recipients, a biopsy 
is mandatory to confirm the diagnosis. If the biopsy is normal or shows minimal disease, then treatment may not be necessary. An adequate biopsy consisting of at least three to five portal zones is necessary for assessment.

Many other factors have to be considered before deciding to treat a particular patient. Most important is to try to assess whether the patient will ever develop cirrhosis and liver failure or, particularly in patients over age 50 years, whether competing causes of mortality are more or less likely to cause death.

Liver biopsy may also be required in patients in whom treatment is not being considered, in order to assess the extent of liver injury. It is recommended that response to treat -5 ment be defined in virological terms. The use of ALT levels to define response to treatment is no longer recommended. Successful treatment is indicated by cleatance of HCV RNA from serum (by sensitive PCR-based assays) six months after the completion of therapy (sustained response). There is evidence showing that this response is durable, in that serum HCV RNA remains negative for years (74). ALT levels return to normal, and the incidence of complications from cirrhosis and HCC is reduced. Survival is improved.

Recommendations: The prime indication for treatment in CHC is an ALT level of more than 1.5 times the upper limit of normal on three consecutive occasions over more than three months.

A liver biopsy is recommended for grading and staging of the liver disease.

It is recommended that response to treatment be defined in virological terms.

Successful treatment is indicated by clearance of $\mathrm{HCV}$ RNA from serum (by sensitive PCR-based assays) 24 weeks after the completion of therapy (sustained response).

Dose and duration of treatment: The recommended treatment for $\mathrm{CHC}$ is with a combination of IFN $-2 \mathrm{~b}$ and ribavirin. The dose of IFN is $3 \mathrm{MU}$ TIW. The dose of ribavirin is $1000 \mathrm{mg}$ for patients weighing less than $75 \mathrm{~kg}$ and $1200 \mathrm{mg}$ daily for patients weighing more than $75 \mathrm{~kg}$ (75-77). The use of IFN -2a or other IFNs in combination with ribavirin has not been reported. Overall, about $40 \%$ of patients treated with this combination have a sustained response.

Patients with genotype 2 or 3 have about a $65 \%$ response rate $(76,77)$. Patients with genotype 1 have about a $30 \%$ response rate. The response rates in other genotypes are not as well defined. Response rates are also improved with lower viral loads (less than $2 \times 10^{6}$ copies/mL by the NGI SuperQuant assay), age less than 40 years, absence of fibrosis and being female (77).

Treatment duration with IFN and ribavirin is determined by the viral genotype. Patients who carry genotypes 2 or 3 may be treated for 24 weeks. Patients carrying any other genotype should be treated for 48 weeks $(53,54)$. Viral load may be used to predict response to therapy, but the data on viral load as an indicator of duration of treatment were weaker than for genotype, and viral load should not, at this stage, be used to determine duration of therapy. An algorithm has been developed using several of the favourable response factors listed above (77). However, the algorithm has not been prospectively validated and should not be used to determine treatment duration.

Unlike patientson IFN monotherapy, a small number of 5 patients treated witb $\mathrm{FFN}$ and ribavirin who ultimately become long term responders first clear HCV RNA between 12 and 24 weeks of therapy.

There are as yet insufficient data to recommend whether the 12-week stop rule described for IFN monotherapy (see below) also applies to combination therapy.

Approximately $14 \%$ of patients with positive HCV RNA assays at 12 weeks become sustained responders. However, patients who fail to clear HCV RNA by 24 weeks of treatment do not become sustained responders. Therefore, a positive HCV RNA assay after 24 weeks of therapy is an indication to stop treatment.

IFN monotherapy should be reserved for patients who cannot tolerate ribavirin (eg, patients with anemia). The intended treatment duration of IFN monotherapy is 48 weeks. Response is assessed at three months using the qualitative HCV RNA test. Failure to clear HCV RNA after three months of therapy predicts inability to develop a sustained response. Treatment should be stopped if the HCV RNA is positive at three months.

Recommendations: The recommended treatment for $\mathrm{CHC}$ is a combination of IFN $-2 \mathrm{~b}$ and ribavirin. The dose of IFN is $3 \mathrm{MU}$ TIW, and the dose of ribavirin is $1000 \mathrm{mg} /$ day for patients weighing less than $75 \mathrm{~kg}$ and $1200 \mathrm{mg} /$ day for patients weighing more than $75 \mathrm{~kg}$.

Patients with HCV genotype 2 or 3 may be treated for 24 weeks. Patients with any other genotype should be treated for 48 weeks.

A positive HCV RNA assay after 24 weeks of therapy is an indication to stop treatment.

IFN monotherapy should be reserved for patients who cannot tolerate ribavirin.

Monitoring during therapy: The addition of ribavirin to IFN therapy increases the likelihood of side effects. Ribavirin predictably causes hemolysis. The hemoglobin level falls within the first two to four weeks, then stabilizes in most patients. Ribavirin dose reduction is recommended if the hemoglobin level falls below $100 \mathrm{~g} / \mathrm{L}$. Routine monitoring for adverse effects includes a complete blood count (CBC) weekly for the first month, then a CBC monthly and a thyroid-stimulating hormone level test every three months. (There is an increased incidence of thryroiditis on IFN ther- 
apy, particularly in patients with CHC.) Symptoms should be monitored monthly during treatment.

Treatment response is to be monitored by the ALT and the HCV RNA concentration. ALT is an imperfect surrogate marker for viral clearance, so HCV RNA testing is mandatory at the appropriate time points (at 12 or 24 weeks of therapy and 24 weeks after completion of therapy). Qualitative HCV RNA testing is adequate to determine response. Quantitative HCV RNA is not required.

Contraindications to therapy: In assessing whether a patient is a good candidate for therapy with IFN and ribavirin, it is essential to consider the benefits and risks for that individual. Factors that may decrease the likelihood of long term benefit from treatment include shorter life expectancy, eg, older age, comorbid conditions, decompensatediver disease and active alcohol abuse (abuse within previous six months). Ideally patients should abstain from alcohol completely while on treatment.

Factors that may predispose patients to a higher risk of adverse events include major psychiatric disorders, cardiovascular diseases (such as significant arrhythmias, major congestive heart failure, uncontrolled hypertension or ischemic heart disease), active autoimmune diseases, poorly controlled seizure disorders, diabetic retinopathy (IFN can exacerbate diabetic retinopathy) or thyroid disease (relative contraindication).

IFN can cause an autoimmune thyroiditis. However, patients who are hypothyroid cannot suffer any further thyroid harm. Other factors increasing the risk of adverse events include myelosuppression, such as thrombocytopenia and neutropenia. Therapy should not be instituted if the platelet count is less than $80 \times 10^{9} / \mathrm{L}$ or if the neutrophil count is less than $1.0 \times 10^{9} / \mathrm{L}$. Renal failure and anemia increase the risk of adverse effects from the ribavirin.

Ribavirin is teratogenic. Patients on combination therapy and their partners must use adequate contraception. $\mathrm{Pa}$ tients in whom poor compliance is expected or in whom there is a significant risk of re-infection, for example, active substance abuse, may not be suitable candidates for treatment. Other conditions that are relative contraindications include severe asthma, psoriasis and past history of autoimmune diseases or psychiatric disorders.

Absolute contraindications to therapy with IFN and ribavirin are decompensated liver disease, active alcohol abuse, pregnancy, or lack of appropriate contraception and expected noncompliance.

Recommendations: In assessing whether a patient is a good candidate for therapy with IFN and ribavirin, it is essential to consider the benefits and risks for that individual.

Absolute contraindications to therapy with IFN and ribavirin are decompensated liver disease, active alcohol abuse, pregnancy, or lack of appropriate contraception and expected noncompliance.
Special cases - Thalassemia: Patients with thalassemia can be offered therapy with the understanding that during treatment there is likely to be a $40 \%$ to $90 \%$ increase in their transfusion requirements. It may be possible to reduce the ribavirin dose. Data on the need to reduce hepatic iron aggressively by chelation to optimize response to treatment are controversial. Alternatively, thalassemia patients may be better off waiting for long-acting IFNs to become available.

Hemophilia: Patients with hemophilia can be offered therapy $(78,79)$. Pretreatment assessment should include a liver biopsy that may be performed by the transjugular or by plugged percutaneous route with clotting factor coverage.

Methadone maintenance: Patients on methadone maintenance should not be excluded from treatment.

Prisoners: Therapy for incarcerated patients should be individualized based on their expected compliance and risk of reinfection.

Treatment failures - Relapse after IFN monotherapy: Patients who relapse after IFN monotherapy are those in whom the ALT normalized or in whom viral clearance occurred transiently during IFN monotherapy, but who relapsed after completing therapy. These patients should be offered treatment with IFN and ribavirin (80). The expected response rate is similar to that of naive patients.

Recommendation: Patients who relapse after IFN monotherapy should be offered treatment with IFN and ribavirin.

Nonresponders to IFN monotherapy: Nonresponders to IFN monotherapy are patients in whom ALT did not return to normal during therapy or in whom viral clearance from serum was not achieved. There are several treatment options for these patients, each with a response rate of $10 \%$ to $15 \%$. Options include retreatment with IFN and ribavirin, treatment with consensus IFN (81) or induction therapy with IFN. There is insufficient information to make a recommendation on the effectiveness of any of the therapeutic options for patients who are nonresponders to IFN monotherapy.

Recommendations: There is insufficient information to make a recommendation on the effectiveness of any therapeutic option for patients who were nonresponders to IFN monotherapy.

Failure of combination therapy: Patients who fail to respond to combination therapy or who relapse afterwards should be managed in consultation with a centre with expertise in this area. There are no proven treatment options for these patients, but they may be candidates for experimental therapies. 
Recommendation: There are no proven treatment options for patients who fail to respond to combination therapy or who relapse afterwards.

Hepatitis C infection in children: In the past, hepatitis C was found with high prevalence in children who received multiple transfusions of blood-derived products before testing for hepatitis $\mathrm{C}$ was introduced. Currently, age-related dis tribution of infection is likely related to different patterns of exposure. Vertical transmission in infants, and bodypiercing, tattooing and drug abuse in adolescents are the most common routes of infection.

The rate at which the initial infection becomes chronic in infants is still unknown. Up to $30 \%$ of these children appear to have spontaneous resolution of their infection. Although progression of the disease seems to be more benign in children than in adults, some children develop significant fibrosis. Uncontrolled trials suggest that the response rate to IFN may be as high as 33\% to 50\% (82-84). The response to combination therapy (IFN and ribavirin) is unknown.

The indications for treatment in children with hepatitis $\mathrm{C}$ have not been adequately defined. $\mathrm{CHC}$ in children should not be treated except in controlled trials.

Recommendation: $\mathrm{CHC}$ in children should not be treated except in controlled trials.

Acute hepatitis C: Since 1991, the routine screening of blood products has decreased the prevalence of acute HCV following transfusion to negligible levels. Therefore, acute $\mathrm{HCV}$ infection is now seen mainly in individuals who have received an accidental needlestick injury. Although risk of infection from an accidental needlestick injury is relatively low - less than $5 \%$ - because the majority of these individuals are health care workers, an early diagnosis is crucial to minimize the risk of nosocomial transmission.

There are no data to indicate which testing algorithms, using serological tests or PCR assays, are more cost effective. HCV RNA may become positive as early as two weeks after exposure. Anti-HCV usually becomes positive 10 weeks after exposure. Early treatment of acute hepatitis $\mathrm{C}$ with IFN monotherapy may enhance the likelihood of response compared with that seen with similar early treatment of CHC (85-87). Whether early treatment with IFN and ribavirin enhances response is unknown.

The possibility of an enhanced response to early therapy has to be balanced against the theoretical $20 \%$ chance of spontaneous clearance of the virus. No recommendations can be made about the timing of therapy of acute hepatitis $\mathrm{C}$. The following recommendation is, therefore, based on expert opinion, rather than on evidence from the medical literature.

Health care workers or others subjected to needlestick injury or equivalent exposure should be tested by anti-HCV at the time of injury and at 12 weeks or later to detect infection.
Treatment should be with standard combination therapy of IFN and ribavirin for the standard duration despite the lack of prospective studies proving efficacy. Given the urgent need to gather data on such cases it is strongly recommended that patients with acute hepatitis $\mathrm{C}$ be treated in the setting of a clinical trial or a registry.

Recommendations: No recommendations can be made about the timing of therapy of acute hepatitis C. Health care workers or others subjected to needlestick injury or equivalent exposure should be tested by anti-HCV at the time of the injury and at 12 weeks to detect infection. Treatment should be with standard combination therapy of IFN and ribavirin for the standard duration, despite the lack of prospective studies proving efficacy. Given the urgent need to gather data on such cases it is strongly recommended that patients with acute hepatitis $\mathrm{C}$ be treated in the setting of a clinical trial or a registry.

\section{COMBINED INFECTIONS}

\section{Hepatitis B and hepatitis C}

The prevalence in Canada of infection with both hepatitis $B$ and $\mathrm{C}$ is unknown. Elsewhere, the prevalence ranges between $3.4 \%$ and $18.3 \%$ in series of patients with hepatitis C (88-90). Various studies have demonstrated that the outcome of combined infection is more severe than that of infection with either virus alone $(91,92)$. In most patients, one infection predominates, while the other is dormant. Thus, in HBV-dominant disease, the HBV DNA is detectable, while the HCV RNA is not, and vice versa. Occasionally both diseases may be active.

The risk of HCC is also increased in those with combined infection, compared with the risk of patients with hepatitis B or hepatitis $\mathrm{C}$ alone (93-96). There are few reports of treatment (97).

In patients with one infection dominant and the other dormant, the indications for treatment, and the dose and duration of treatment are identical to those when the dominant disease exists on its own. For example, in patients who are $\mathrm{HBeAg}$-positive with detectable HBV DNA, undetectable HCV RNA, and elevated aminotransferase levels, treatment is IFN 27 to $36 \mathrm{MU}$ weekly for four months. Conversely, if the HBV DNA is undetectable, and HCV RNA is present, treatment is IFN and ribavirin for 24 or 48 weeks, as dictated by the hepatitis $\mathrm{C}$ genotype

\section{Hepatitis B and HIV}

Because hepatitis B and HIV are spread in similar ways, patients often have evidence of infection with both agents. However, only about $10 \%$ of HIV-positive subjects are chronic carriers of hepatitis B. In the presence of HIV infection hepatitis B replication is increased, and liver disease is more common and tends to progress more rapidly. However, until the advent of highly active antiretroviral therapy, most patients who were co-infected with hepatitis B and HIV died 
of AIDS, rather than complications of hepatitis B. This may no longer be true now that more effective anti-HIV therapy is available.

IFN treatment of hepatitis B in HIV-positive patients has been largely unsuccessful $(31,32,98)$. Lamivudine therapy is effective in suppressing viral replication, but there are no reports of long term outcome after lamivudine therapy in this population. Because lamivudine is a component of highly active antiretroviral therapy, patients co-infected with both viruses may receive appropriate treatment for the hepatitis $\mathrm{B}$ as a fortunate, but not necessarily intended, result of HIV therapy.

Chronic hepatitis B in HIV-infected patients must not be treated with lamivudine monotherapy. Lamivudine monotherapy will result in the rapid emergence of resistant HIV virus.

\section{Hepatitis C and HIV}

Hepatitis C infection occurs in 50\% to $90 \%$ of HIV-positive patients. Co-infection results in hepatitis $\mathrm{C}$ viral loads that are higher than in the absence of HIV $(99,100)$. Progression to cirrhosis is also more rapid (100). Treatment with IFN monotherapy has a success rate similar to that of hepatitis $\mathrm{C}$ in the absence of HIV (about 15\%)(101-104). There are no data on the use of combination therapy with IFN and ribavirin in these patients. There are no recommendations about therapy in patients co-infected with hepatitis C and HIV.

Recommendations: In patients who are HBeAg-positive with detectable HBV DNA, undetectable HCV RNA, and elevated aminotransferase levels, treatment is IFN 27 to $36 \mathrm{MU}$ weekly for four months. In patients who are HBeAg-positive with detectable HBV DNA, undetectable HCV RNA and elevated aminotransferase levels, treatment is IFN 27 to $36 \mathrm{MU}$ weekly for four months. Chronic hepatitis B in HIV-infected patients must not be treated with lamivudine monotherapy. There are no recommendations about therapy in patients co-infected with hepatitis C and HIV.

\section{SCREENING PATIENTS WITH CHRONIC HEPATITIS B AND HEPATITIS C FOR HCC}

HCC is a well known complication of chronic HBV infection. The risk of HCC appears to be related to the duration of infection. Thus, Asian patients who acquire the disease in childhood are, by virtue of the long duration of the disease, at a significantly higher risk of developing HCC than Alaskan natives or Caucasians $(20,105-107)$. The cumulative probability of developing $\mathrm{HCC}$ in patients who are $\mathrm{HBs} A g$ positive has been estimated to be $6 \%$ at five years and $15 \%$ at 10 years.

Once HCC develops, the prognosis is very poor. Survival of patients with symptomatic untreated tumours beyond three years is rare (108). The enthusiasm to screen patients with HBV for HCC is based on the premise that earlier detection can offer these patients a chance for potential cure.

There are two large North American studies of screening in hepatitis B carriers $(107,109)$. One suggests that screening is very effective at finding curable tumours, whereas the 6 other suggests otherwise.

The risk of eleveloping HCC in a noncirrhotic patient with HCV is trivial. Once cirrhosis is present, the cumulative probability of developing HCC is estimated to be $1.4 \% /$ year to $3.3 \% /$ year $(50,62)$.

Apart from cirrhosis, other factors that increase a patient's risk of developing HCC include long duration of infection, being male, age older than 55 years, continued alcohol consumption and co-infection with HBV. Response to IFN treatment appears to confer a protective effect against HCC development. Although routine screening for $\mathrm{HCC}$ in patients with HCV is not as widespread as for patients with HBV, this is still practised in certain community groups.

Much of what is known about screening for HCC in patients with HBV also applies to patients with HCV. There have been no studies to determine whether screening for HCC decreases the disease-specific mortality. Thus, the most important clue about whether screening is effective is missing. The decision to screen, therefore, must rest on other factors. One of the reasons why screening may not be effective is the poor sensitivity of our screening tests. The currently employed screening tests, which include alpha-fetoprotein and ultrasound, have sensitivities of 50\% and $70 \%$, respectively (107). Furthermore, HCC tends to occur in patients with cirrhosis, many of whom cannot tolerate a curative surgical resection.

Other treatment options are liver transplantation or alcohol injection of the lesions. The former is limited only to patients who are HBV DNA-negative either spontaneously or induced by therapy. The lack of suitable organ donors limits this option. Alcohol injection can be an effective treatment for HCC, but its efficacy is markedly reduced in patients with large tumours (greater than $5 \mathrm{~cm}$ ). Alcohol injection is technically difficult in patients with ascites and coagulopathy.

Screening should be performed only when effective curative therapy is possible and in patient groups where the relative risk of HCC development is high. Screening is also appropriate in patients who have undergone a curative resection for HCC.

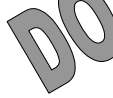


Recommendations: In the absence of documented benefit of mass screening, the committee makes no recommendations for or against screening for $\mathrm{HCC}$ in HBsAg-positive patients or CHC patients. Screening may be justified in high risk cases (presence of cirrhosis, long duration of infection, $\mathrm{HBV} / \mathrm{HCV}$ co-infection, past curative resection for HCC or family history of HCC [HBV only]).

\section{HEPATITIS B VACCINATION}

Hepatitis B vaccination policies vary by province across Canada. All provinces include some form of universal vaccination, offered either to all newborns or to adolescents, as well as vaccination of individuals at high risk of acquiring hepatitis B. Because high risk situations are not always adequately identified, there is a risk that some susceptible individuals will not receive vaccination. Strategies aimed at those entering their teenage years fail to protect against horizontal transmission in children who reside in communities where hepatitis B is endemic. Recent data indicate that in endemic countries, horizontal transmission is more common than previously recognized. Horizontal transmission has also been shown to occur at a high rate in southeast Asian and other immigrant communities in North America (110-112).

The objectives of a universal hepatitis B vaccination policy should be to eliminate vertical (mother to child) transmission, as well as horizontal transmission in early childhood. The policies should also protect against hepatitis B risks imposed by environment, behaviours or occupation. The vaccination strategy for Canada should be universal vaccination of all neonates, combined with screening of all pregnant women.

Newborns of infected mothers should be given hepatitis B immunoglobulin in addition to the vaccine. A catch-up program should be instituted for all children and young adults who have not yet been vaccinated. There should be a standardized national policy, so that vaccination is assured for all children when their families move between provinces.

The seroconversion rate after hepatitis $B$ vaccination in healthy young adults is more than $90 \%$ and in children is more than $98 \%$. Therefore, serological testing postimmunization is not recommended routinely. It is recommended, however, for those with continual or repeated exposures. This would apply to infants of infected mothers, sexual partners of chronic carriers and those with occupational exposure. For further details see the Canadian Immunization Guide (113).
TABLE 7

Recommended usage for pre-exposure prophylaxis against hepatitis A - Potential candidates for the vaccine

Travellers to countries where hepatitis A is endemic, especially when travel involves rural or primitive conditions

Residents of communities with high endemic rates or recurrent outbreaks of HAV

Member mers of the armed forces, emergency relief workers and others Tikely to be posted abroad at short notice to areas with high rates of HAV infection

Residents and staff of institutions for the developmentally challenged where there is an ongoing problem with HAV transmission

Inmates of correctional facilities in which there is an ongoing problem with HAV infection

People with lifestyle-determined risks of infection, including those engaging in oral or intravenous illicit drug use in unsanitary conditions

Men who have sex with men

People with chronic liver disease who may not be at increased risk of infection but who are at increased risk of fulminant hepatitis A

Others, such as patients with hemophilia A or B receiving plasma-derived replacement clotting factors; zoo-keepers, veterinarians and researchers who handle nonhuman primates; certain workers involved in research on HAV or production of hepatitis A vaccine

HAV Hepatitis A virus

Recommendations: The vaccination strategy for Canada should be universal vaccination of all neonates, combined with screening of all pregnant women. Newborns of infected mothers should be given hepatitis $\mathrm{B}$ immunoglobulin in addition to the vaccine. A catch-up program should be instituted for all children and young adults who have not yet been vaccinated. There should be a standardized national policy so that vaccination is assured for all children if their families move between provinces. Serological testing postimmunization is not recommended routinely.

\section{HEPATITIS A VACCINATION}

The age distribution and number of hepatitis A-susceptible individuals in Canada have changed over the past 20 years. An increasing percentage of adults have never been exposed to hepatitis A and remain at risk of infection. Hepatitis A in childhood is usually a trivial disease. However, in adults, hepatitis A can be severe, with considerable morbidity and even mortality.

In addition, some studies have suggested that acute hepatitis A infection in patients with chronic liver disease may also cause severe disease, including death (114). However, it is not clear whether the risk of severe hepatitis A is related to the severity of the underlying liver disease or to other factors.

Hepatitis A vaccines are safe and effective. Patients with 


\section{The Canadian Association for Study of the Liver (CASL) Consensus Conference on Viral Hepatitis}

\section{Consensus Panel Participants:}

Eric Yoshida, Christopher Sherlock, Richard Schreiber University of British Columbia, Vancouver, British Columbia Mel Krajden BC Centers for Disease Control, Vancouver, British Columbia

Mark Joffe, Winnie Wong, Klaus Gutfreund University of Alberta, Edmonton, Alberta

Sam Lee

University of Calgary, Calgary, Alberta

Gerry Minuk, Barry Rosser, Kelly Kaita University of Manitoba, Winnipeg, Manitoba

Cameron Ghent

University of Western Ontario, London, Ontario

Helga Witt-Sullivan

McMaster University, Hamilton, Ontario

Jenny Heathcote, Morris Sherman (Chairman), Victor Feinman, Eve Roberts

University of Toronto, Toronto, Ontario

Linda Scully

University of Ottawa, Ottawa, Ontario

Bernard Willems, Jean Pierre Villeneuve, Steven Martin University of Montreal, Montreal, Quebec

Averell Sherker, Marc Deschenes

McGill University, Montreal, Quebec

Kevork Peltekian

Dalhousie University, Halifax, Nova Scotia

Pierre Pare

Laval University, Laval, Quebec

\section{This report was written by a committee consisting of:}

\section{Chairman: Eldon Shaffer \\ University of Calgary, Calgary, Alberta}

Florence Wong, Susan King, Morris Sherman University of Toronto, Toronto, Ontario

Fernando Alvarez

University of Montreal, Montreal, Quebec

William Depew

Queen's University, Kingston, Ontario

Jutta Preiksaitis

University of Alberta, Edmonton, Alberta compensated cirrhosis appear to respond adequately to the hepatitis A vaccine (115). Recommendations by the National Advisory Committee on Immunization (NACI) regarding populations in whom vaccination is appropriate, remain pertinent (116) (Table 7).

The cost effectiveness of a universal strategy of hepatitis A vaccination in Canada is not known. There is limited information on the long term benefit of hepatitis A vaccination in patients with chronic liver disease. Although universal yaccination for hepatitis $\mathrm{A}$ is a worthy goal, its role in any unified strategy for disease prevention remains to be determined.

Recommendation: Recommendations by NACI regarding populations in whom vaccination is appropriate remain pertinent.

\section{HEPATITIS G VIRUS}

Hepatitis $\mathrm{G}$ virus (HGV) is a flavivirus, which shares about $27 \%$ to $40 \%$ sequence homology with HCV (117). HGV is identical to the 'GB-C' agent originally found in a surgeon with hepatitis and later identified in animals to be different from hepatitis viruses A, B, C, D and E. Studies on posttransfusion hepatitis in HGV RNA-positive blood donors and in those with community-acquired acute hepatitis have suggested that HGV is not an important cause of chronic liver disease $(118,119)$. Some patients who acquired hepatitis $G$ from transfusion have developed a mild transient aminotransferase elevation that resolves spontaneously (120).

Although the virus may persist, it appears that chronic liver disease does not ensue. Further, the liver is not the primary site of HGV replication (121). There is a high prevalence of $\mathrm{HGV}$ in blood donors, perhaps in the order of $1 \%$ to $2 \%$. Fulminant hepatitis is rare.

$\mathrm{HGV}$ is transmitted by intravenous and sexual routes, and perhaps via perinatal transmission. Its presence in liver transplant recipients does not affect the outcome of the disease (122). Routine screening of blood donors or widespread testing for $\mathrm{HGV}$ is not recommended. Diagnosis requires virological methods based on PCR or serological assays using the E2 antibody. Neither of these is readily available.

Recommendation: Routine screening of blood donors or widespread testing for $\mathrm{HGV}$ is not recommended.

TRANSFUSION-TRANSMITTED VIRUS

Transfusion-transmitted virus is a recently described virus $(123,124)$. Its epidemiology and disease associations are unknown. Viremia is common (125), but there is no known association with liver disease. There are no commercially available kits to assay for this virus. Therefore, no active attempt at diagnosing this infection is required. 
Recommendation: No active attempt at diagnosing transfusion-transmitted virus infection is required.

\section{REFERENCES}

1. Wong WW, Minuk GY. A cross-sectional seroepidemiologic survey of chronic hepatitis B virus infections in Southeast Asian immigrants residing in a Canadian urban centre. Clin Invest Med 1994:17:443-7.

2. Sweet LE, Brown MG, Lee SH, Liston RM, MacDonald MA, Forward KR. Hepatitis B prenatal screening survey, Nova Scotia, 1990-1991. Can J Public Health 1993;84:279-82.

3. Chernesky MA, Blajchman MA, Castriciano S, Basbaum J, Spivak C, Mahony JB. Analysis of a pregnancy-screening and neonatal-immunization program for hepatitis B in Hamilton, Ontario, Canada, 1977-1988. J Med Virol 1991;35:50-4.

4. Delage G, Montplaisir S, Remy-Prince S, Pierri E. Prevalence of hepatitis B virus infection in pregnant women in the Montreal area. Can Med Assoc 1986;134:897-901.

5. Minuk GY, Nicolle LE, Postl B, Waggoner JG, Hoofnagle JH, Hepatitis virus infection in an isolated Canadian Inuit (Eskimo) population. J Med Virol 1982;10:255-64.

6. Baikie M, Ratnam S, Bryant DG, Jong M, Bokhout M. Epidemiologic features of hepatitis B virus infection in Northern Labrador. Can Med Assoc J 1989;141:791-5.

7. Fattovich G, Giustina G, Schalm SW, et al. Occurrence of hepatocellular carcinoma and decompensation in western European patients with cirrhosis type B. The EUROHEP Study Group on Hepatitis B Virus and Cirrhosis. Hepatology 1995;21:77-82.

8. Lok AS, Lai CL. A longitudinal follow-up of asymptomatic hepatitis B surface antigen-positive Chinese children. Hepatology 1988;8:1130-3.

9. Gupta S, Govindarajan S, Fong TL, Redeker AG. Spontaneous reactivation in chronic hepatitis B patterns and natural history. J Clin Gastroenterol 1990;12:562-8.

10. Fattovich G, Brollo L, Alberti A, et al. Spontaneous reactivation of hepatitis $B$ virus infection in patients with chronic type $B$ hepatitis. Liver 1990;10:141-6.

11. Lok AS, Lai CL. Acute exacerbations in Chinese patients with chronic hepatitis B virus infection. Incidence, predisposing factors and etiology. J Hepatol 1990;10:29-34.

12. Lok AS, Lai CL, Wu PC, Leung EK, Lam T. Spontaneous hepatitis B e antigen to antibody serconversionand reversion in Chinese patients with chronic hepatitis B virus infection. Gastroenterology 1987;92:1839-43.

13. Fattovich $\mathrm{G}$, Rigge M, Brollo L, et al. Clinical, virologic and histologic outcome following serconversion from HBeAg to anti-HBe in chronic hepatitis type B. Hepatology 1986;6:167-72.

14. de Franchis R, Meucci G, Vecchi M, et al. The natural history of symptomatic hepatitis B surface antigen carriers. Ann Intern Med 1993;118:191-4.

15. Fattovich G, Guistina G, Sanchez-Tapias J, et al. Delayed clearance of serum HBsAg in compensated cirrhosis B: relation to interferon alpha therapy and disease prognosis. European Concerted Action on Viral Hepatitis (EUROHEP). Am J Gastroenterol 1998;93:896-900.

16. Koh KC, Lee HS, Kim CY. Universal emergence of precore mutant hepatitis $\mathrm{B}$ virus along with seroconversion to anti-HBe irrespective of subsequent activity of chronic hepatitis B. Korean J Intern Med 1994;9:61-6.

17. Realdi G, Fattovich G, Hadziyannis S, et al. Survival and prognostic factors in 366 patients with compensated cirrhosis type B: a multi-center study. The investigators of the European Concerted Action on Viral Hepatitis (EUROHEP). J Hepatol 1994;21:656-66.

18. de Jongh FE, Janssen HL, de Man RA, Hop WC, Schalm SW, van Blankenstein M. Survival and prognostic indicators in hepatitis B surface antigen-positive cirrhosis of the liver. Gastroenterology 1992;103:1630-5

19. Fattovich G, Brollo L, Guistina G, et al. Natural history and prognostic factors for chronic hepatitis type B. Gut 1991;32:194-8.

20. Beasley RP, Hwang LY, Lin CC, Chien CS. Hepatocellular carcinoma and hepatitis B virus. A prospective study of 22,707 men in Taiwan. Lancet 1981;ii:1129-33.

21. Lai CL, Chien RN, Leung NW, et al. A one-year trial of lamivudine for chronic hepatitis B. Asia Hepatitis Lamivudine Study Group. N Engl J Med 1998;339:61-8

22. Heathcote J, Schalm S, Ciancara J, et al. Lamivudine and intron A combination treatment in chronic hepatitis B infection. Hepatology 1998;28(Suppl):43

23. Schiff E, Karayalcin S, Grimm I, et al. A placebo-controlled study of lamivudine and interferon alpha $2 \mathrm{~b}$ in patients with chronic hepatitis B who previously failed interferon therapy. Hepatology 1998;28(Suppl):43.
24. Allen MI, Deslauriers M, Andrews CW, et al. Identification and characterization of mutations in hepatitis B virus resistant to lamivudine. Lamivudine Clinical Investigation Group. Hepatology 1998;27:1670-7.

25. Di Bisceglie AM, Fong TL, Fried MW, et al. A randomized controlled trial of recombinant alpha interferon therapy for chronic hepatitis B. Am J Gastroenterol 1993;88:1887-92.

26. Lok AS, Lai CL, Wu PC, Leung EK. Long-term follow-up in a randomized controlled trial of recombinant interferon alpha- 2 in Chinese patients with chronic hepatitis B infection. Lancet 1988;ii:298-302.

27. Lai CL, Lok AS, Lin HJ, Wu PC, Yeoh EK, Yeung CY. Placebo-controlled trial of recombinantalpha-2 interferon in Chinese HBsAg-carrier children. Lancet 1987;ii:877-80. Krogsgaard K, Bindslev N, Christensen E, et al. The treatment effect of alpha interferon in chronic hepatitis B is independent of pre-treatment variables. Results based on individual patient data from 10 clinical controlled trials. European Concerted Action on Viral Hepatitis (Eurohep). J Hepatol 1994;21:646-55.

. Thomas HC, Lok AS, Carreno V, et al. Comparative study of three doses of interferon-alpha $2 \mathrm{a}$ in chronic active hepatitis B. The International Hepatitis Trial Group. J Viral Hepatol 1994;1:139-48.

30. Brook MG, McDonald JA, Karayiannis P, et al. Randomized controlled trial of interferon alfa 2A (rbe) (Roferon-A) for the treatment of chronic hepatitis $\mathrm{B}$ virus (HBV) infection: factors that influence response. Gut 1989;30:1116-22.

31. Wong DK, Yim C, Naylor CD, et al. Interferon alfa treatment of chronic hepatitis B: randomized trial in a predominantly homosexual male population. Gastroenterology 1995;108:165-71.

32. Brook MG, Karayiannis P, Thomas HC. Which patients with chronic hepatitis B virus infection will respond to alpha-interferon therapy? A statistical analysis of predictive factors. Hepatology 1989;10:761-3

33. Lok AS, Ghany MG, Watson G, Ayola B. Predictive value of aminotransferase and hepatitis B virus DNA levels on response to interferon therapy for chronic hepatitis B. J Viral Hepatol 1998;5:171-8.

34. Fattovich G, McIntyre G, Thursz M, et al. Hepatitis B virus precore/core variation and interferon therapy. Hepatology 1995;22:1355-62.

35. Tassopoulos NC, Volpes R, Pastore G, et al. Efficacy of lamivudine in patients with hepatitis $\mathrm{B}$ e antigen-negative/hepatitis $\mathrm{B}$ virus DNA-positive (precore mutant) chronic hepatitis B. Lamivudine Precore Mutant Study Group. Hepatology 1999;29:889-96.

36. Picardi M, Selleri C, De Rosa G, Raiola A, Pezzullo L, Rotoli B. Lamivudine treatment for chronic replicative hepatitis B virus infection after allogeneic bone marrow transplantation. Bone Marrow Transplant 199;21:1267-9.

37. Brind AM, Bennett MK, Bassendine MF. Nucleoside analogue therapy in fibrosing cholestatic hepatitis - a case report in an HBsAg positive renal transplant recipient. Liver 1998;18:134-9.

38. Lok AS, Lindsay I, Scheuer PJ, Thomas HC. Clinical and histological features of delta infection in chronic hepatitis B virus carriers. J Clin Pathol 1985;38:530-3.

39. Farci P, Mandas A, Coiana A, et al. Treatment of chronic hepatitis D with interferon alfa-2a. N Engl J Med 1994;330:88-94.

40. Perrillo R, Tamburro C, Regenstein F, et al. Low-dose, titratable interferon alfa in decompensated liver disease caused by chronic infection with hepatitis B virus. Gastroenterology 1995;109:908-16.

41. Lin CY.Treatment of hepatitis B virus-associated membranous nephropathy with recombinant alpha-interferon. Kidney Int 1995; 47:225-30.

42. Conjeevaram HS, Hoofnagle JH, Austin HA, Park Y, Fried MW, Di Bisceglie AM. Long-term outcome of hepatitis B virus-related glomerulonephritis after therapy with interferon alfa. Gastroenterology 1995; 109:540-6.

43. Bortolotti F, Faggion S, Con P. Natural history of chronic kiral hepatitis in childhood. Acta Gastroenterol Belg 1998 61:198-20

44. Sokal EM, Conjeevaram HS, Roberts EA, et al. Interferon alfa therapy for chronic hepatitis B in children: a multinational randomized controlled trial. Gastroenterology 1998;114:988-95.

45. Robertson B, Myers G, Howard C, et al. Classification, nomenclature, and database development for hepatitis $\mathrm{virus}(\mathrm{HCV})$ and related viruses: proposals for standardization. International Committee on Virus Taxonomy. Arch Virol 1998:143:2493-503.

46. Murphy DG, Willems B, Delage G, et al. Hepatitis C virus genotypes in patients and blood donors. Can Commun Dis Rep 1995;21:129-32.

47. Bernier L, Willems B, Delage G, Murphy DG. Indentification of numerous hepatitis $\mathrm{C}$ virus genotypes in Montreal, Canada. J Clin Microbiol 1996;34:2815-8.

48. Altamirano M, Delaney A, Wong A, Maronstenmaki J, Pi D. Identification of hepatitis $\mathrm{C}$ virus genotypes among hospitalized patients in British Columbia, Canada. J Infect Dis 1995;171:1034-8.

49. Andonov A, Chaudhari RK. Genotyping of Canadian hepatitis C virus isolates by PCR. J Clin Microbiol 1994;32:2031-4. 
50. Tong MJ, el-Farra NS, Reikes AR, Co RL. Clinical outcomes after transfusion-associated hepatitis C. N Engl J Med 1995;332:1463-6.

51. Pol S, Fontaine H, Carnot F, et al. Predictive factors for development of cirrhosis in parenterally acquired chronic hepatitis C: a comparison between immunocompetent and immunocompromised patients. J Hepatol 1998;29:12-9.

52. Niederau C, Lange S, Heintges T, et al. Prognosis of chronic hepatitis C: results of a large, prospective cohort study. Hepatology 1998;28:1687-95.

53. Wiley TE, McCarthy M, Breidi L, McCarthy M, Layden TJ. Impact of alcohol on the histological and clinical progression of hepatitis $\mathrm{C}$ infection. Hepatology 1998;28:805-9.

54. Pol S, Lamothe B, Thi NT, et al. Retrospective analysis of the impact of HIV infection and alcohol use on chronic hepatitis $\mathrm{C}$ in a large cohort of drug users. J Hepatol 1998;28:945-50.

55. Pessione F, Degos F, Marcellin P, et al. Effect of alcohol consui serum hepatitis $\mathrm{C}$ virus RNA and histological lesions in thronic hepatitis C. Hepatology 1998;27:1717-22

56. Yano M, Kumada H, Kage M, et al. The long-term pathological evolution of chronic hepatitis C. Hepatology 1996;23:1334-40.

57. Roudot-Thoraval F, Bastie A, Pawlotsky JM, Dhumeaux D. Epidemiological factors affecting the severity of hepatitis Carirus-related liver disease: a French survey of 6,664 patients. The Study Group for the Prevalence and the Epidemiology of Hepatitis GVirus. Hepatology 1997;26:485-90.

58. Sobesky R, Mathurin P, Charlotte F, et al. Modeling the impact of interferon alfa treatment on liver fibrosis progression in chronic hepatitis C: a dynamic view. The Multivirc Group. Gastroenterology 1999;116:378-86

59. Kenny-Walsh E. Clinical outcomes after hepatitis C infection from contaminated anti-D immune globulin. Irish Hepatology Research Group. N Engl J Med 1999;340:1228-33.

60. Mathurin P, Moussalli J, Cadranel JF, et al. Slow progression rate of fibrosis in hepatitis $\mathrm{C}$ virus patients with persistently normal alanine transaminase activity. Hepatology 1998;27:868-72.

61. Poynard T, Bedossa P, Opolon P. Natural history of liver fibrosis progression in patients with chronic hepatitis C. The OBSVIRC, METAVIR, CLINIVIR, and DOSVIRC groups. Lancet 1997;349:825-32

62. Fattovich G, Giustina G, Degos F, et al. Morbidity and mortality in compensated cirrhosis type C: a retrospective follow-up study of 384 patients. Gastroenterology 1997;112:463-72.

63. Piazza M, Sagliocca L, Tosone G, et al. Sexual transmission of the hepatitis $\mathrm{C}$ virus and efficacy of prophylaxis with intramuscular immune serum globulin. A randomized controlled trial. Arch Intern Med 1997;157:1537-44.

64. Kao JH, Liu CJ, Chen PJ, et al. Interspousal transmission of GB virus-C/hepatitis $G$ virus: a comparison with hepatitis $C$ virus. J Med Virol 1997;53:348-53.

65. Comandini UV, Tossini G, Longo MA, Ferri F, Cuzzi G, Noto P. Sporadic hepatitis $\mathrm{C}$ virus infection: a case-control study of transmission routes in a selected hospital sample of the general population in Italy. Scand J Infect Dis 1998;30:11-5

66. Eyster ME, Alter HJ, Aledort LM, Quan S, Hatzakis A, Goedert JJ. Heterosexual co-transmission of hepatitis $\mathrm{C}$ virus (HCV) and human immunodeficiency virus (HIV). Ann Intern Med 1991;115:764-8.

67. Thomas DL, Zenilman JM, Alter HJ, et al. Hepatitis C, hepatitis B, and human immunodeficiency virus infections among non-intravenous drug-using patients attending clinics for sexually transmitted diseases. J Infect Dis 1994:169:990-5.

68. Akahane Y, Kojima M, Sugai Y, et al. Hepatitis C virus infection in spouses of patients with type $\mathrm{C}$ chronic liver disease. Ann Intern Med 1994;120:748-52.

69. Caporaso N, Ascione A, Stroffolini T. Spread of hepatitis C virus infection within families. Investigators of an Italian Multicenter Group. J Viral Hepatol 1998;5:67-72.

70. Ohto H, Terazawa S, Sasaki N, et al. Transmission of hepatitis $\mathrm{C}$ virus from mothers to infants. The Vertical Transmission of Hepatitis C Virus Collaborative Study Group. N Engl J Med 1997;330:744-50.

71. Zanetti AR, Tanzi E, Romano L, et al. A prospective study on mother-to-infant transmission of hepatitis $\mathrm{C}$ virus. Intervirology 1998;41:208-12.

72. Meisel H, Reip A, Faltus B, et al. Transmission of hepatitis $C$ virus to children and husbands by women infected with contaminated anti-D immunoglobulin. Lancet 1995;345:1209-11.

73. Thomas DL, Villano SA, Riester KA, et al. Perinatal transmission of hepatitis $\mathrm{C}$ virus from human immunodeficiency virus type 1 -infected mothers. Women and Infants Transmission Study. J Infect Dis $1998 ; 177: 1480-8$
74. Marcellin P, Boyer N, Gervais A, et al. Long-term histologic improvement and loss of detectable intrahepatic HCV RNA in patients with chronic hepatitis $\mathrm{C}$ and sustained response to interferon-alpha therapy. Ann Intern Med 1997;127:875-81.

75. Reichard O, Norkrans G, Fryden A, Braconier JH, Sonnerborg A, Weiland O. Randomised, double-blind, placebo-controlled trial of interferon alpha-2b with and without ribavirin for chronic hepatitis C. The Swedish Study Group. Lancet 1998;351:83-7.

76. McHutchison JG, Gordon SC, Schiff ER, et al. Interferon alfa-2b alone or in combination with ribavirin as initial treatment for chronic hepatitis C. Hepatitis Interventional Therapy Group. N Engl J Med 1998;339:1485-92. . Poynard T, Marcellin P, Lee SS, et al. Randomised trial of interferon alpha2b plus ribavirin for 48 weeks or for 24 weeks versus interferon alpha $2 \mathrm{~b}$ plus placebo for 48 weeks for treatment of chronic infection with hepatitis $\mathrm{C}$ virus. International Hepatitis Interventional Therapy Group. Lancet 1998;352:1426-32.

78. Laursen AL, Scheibel E, Ingerslev J, et al. Alpha interferon therapy in Danish hemophiliac patients with chronic hepatitis C: results of a randomized controlled open label study comparing two different maintenance regimens following standard interferon alpha $2 \mathrm{~b}$ treatment. Haemophilia 1998;4:25-32.

79. Rumi MG, Santagostino E, Morfini M, et al. A multicenter controlled randomized open label trial of interferon alpha $2 \mathrm{~b}$ treatment of anti-human immunodeficiency virus-negative hemophiliac patients with chronic hepatitis C. Hepatitis Study Group of the Italian Hemophilia Centers. Blood 1997;89:3529-33.

80. Davis GL, Esteban-Mur R, Rustgi V, et al. Interferon alfa-2b alone or in combination with ribavirin for the treatment of relapse of chronic hepatitis C. International Hepatitis Interventional Therapy Group. N Engl J Med 1998;339:1493-9.

81. Heathcote EJ, Keeffe EB, Lee SS, et al. Re-treatment of chronic hepatitis C with consensus interferon. Hepatology 1998;27:1136-43.

82. Garcia-Monzon C, Jara P, Fernandez-Bermejo M, et al. Chronic hepatitis C in children: a clinical and immunohistochemical comparative study with adult patients. Hepatology 1998;28:1696-701.

83. Iorio R, Pensati P, Porzio S, Fariello I, Guida S, Vegnente A. Lymphoblastoid interferon alfa treatment in chronic hepatitis C. Arch Dis Child 1996;74:152-6.

84. Bortolotti F, Giacchino R, Vajro P, et al. Recombinant interferon-alfa therapy in children with chronic hepatitis C. Hepatology 1995;22:1623-7.

85. Viladomiu L, Genesca J, Esteban JI, et al. Interferon-alpha in acute posttransfusion hepatitis C: a randomized, controlled trial. Hepatology 1992;15:767-9

86. Hwang SJ, Lee SD, Chan CY, Lu RH, Lo KJ. A randomized controlled trial of recombinant interferon alpha- $2 \mathrm{~b}$ in the treatment of Chinese patients with acute post-transfusion hepatitis C. J Hepatol 1994;21:831-6.

87. Lampertico P, Rumi M, Romeo R, et al. A multicenter randomized controlled trial of recombinant interferon-alpha $2 \mathrm{~b}$ in patients with acute transfusion-associated hepatitis C. Hepatology 1994;19:19-22.

88. Crespo J, Lozano JL, de la Cruz F, et al. Prevalence and significance of hepatitis $\mathrm{C}$ viremia in chronic active hepatitis B. Am J Gastroenterol 1994;89:1147-51.

89. Chan CY, Lee SD, Wu JC, et al. Superinfection with hepatitis C virus in patients with symptomatic chronic hepatitis B. Scand J Infect Dis 1991;23:421-4.

90. Sato S, Fujiyama S, Tanaka M, et al. Coinfection of hepatitis C virus in patients with chronic hepatitis B infection. J Hepatol 1994:21:159-66.

91. Serfaty L, Aumaitre H, Chazouilleres O, et al. Determinants of outcome of compensated hepatitis $\mathrm{C}$ virus-related cirrhosis. Hepatology 1998;27:1435-40.

92. Fong TL, Di Bisceglie AM, Waggoner JG, Banks SM, Hoofnagle JH. The significance of antibody to hepatitis $\mathrm{C}$ virus in patients with chronic hepatitis B. Hepatology 1991;14:64-7.

93. Benvengu L, Fattovich G, Noventa F, et al. Goncurrent hepatitis B and C virus infection and risk of hepatocellular carcinoma in cirrhosis. Cancer 1994;74:2442-8.

94. Pontisso P, Ruvoletta MG, Fattovich G, et al. Clinical and virological profiles in patients with multiple hepatitis virus infections. Gastroenterology 1993;105:1529-33.

95. Zarski JP, Bohn B, Bastie A, et al. Characteristics of patients with dual infection by hepatitis B and C viruses. J Hepatol 1998;28:27-33.

96. Chiba T, Matsuzaki Y, Abei M, et al. Multivariate analysis of risk factors for hepatocellular carcinoma in patients with hepatitis $\mathrm{C}$ virus-related liver cirrhosis. J Gastroenterol 1996;31:552-8.

97. Weltman MD, Brotodihardjo A, Crewe EB, et al. Coinfection with 
hepatitis $\mathrm{B}$ and $\mathrm{C}$ or $\mathrm{B}, \mathrm{C}$ and delta viruses results in severe chronic liver disease and responds poorly to interferon-alpha treatment. J Viral Hepatol 1995;2:39-45.

98. Hess G, Rossol S, Voth R, et al. Treatment of patients with chronic type B hepatitis and concurrent human immunodeficiency virus infection with a combination of interferon alpha and azidothymidine: a pilot study. Digestion 1989;43:56-9.

99. Macias J, Pineda JA, Leal MA, et al. Influence of hepatitis C infection on the mortality of antiretroviral-treated patients with HIV disease. Eur J Clin Microbiol Infect Dis 1998;17:167-70.

100. Ghany MG, Leissinger C, Lagier R, Sanchez-Pescador R, Lok AS. Effect of human immunodeficiency virus infection on hepatitis $\mathrm{C}$ virus infection in hemophiliacs. Dig Dis Sci 1996;41:1265-72.

101. Soriano V, Garcia-Samaniego J, Bravo R, et al. Efficacy and safety-of alpha-interferon treatment for chronic hepatitis C in HIV-infected patients. HIV-Hepatitis Spanish Study Group. J Infect 1995;31:9-13.

102. Mauss S, Klinker H, Ulmer A, et al. Response to treatment of chronic hepatitis $\mathrm{C}$ with interferon alpha in patients infected with HIV-1 is associated with higher CD4+ cell count. Infection 1998;26:16-9.

103. Mauss S, Heintges T, Adams O, Albrecht H, Niederau C, Jablonousski H. Treatment of chronic hepatitis $\mathrm{C}$ with interferon-alpha in patients infected with the human immunodeficiency virus. Hepatogastroenterology 1995;42:528-34

104. Boyer N, Marcellin P, Degott C, et al. Recombinant interferon-alpha for chronic hepatitis $\mathrm{C}$ in patients positive for antibody to human immunodeficiency virus. Comite des Anti-Viraux. J Infect Dis 1992;165:723-6.

105. McMahon BJ, Alberts SR, Wainwright RB, Bulkow L, Lanier AP. Hepatitis $B$ related sequelae. Prospective study of 1400 hepatitis B surface antigen positive Alaskan native carriers. Arch Intern Med 1990;150:1051-4.

106. Villeneuve JP, Desrochers M, Infante-Rivard C, et al. A long-term follow-up study of asymptomatic hepatitis B surface antigen-positive carriers in Montreal. Gastroenterology 1994;106:1000-5.

107. Sherman M, Peltekian KM, Lee C. Screening for hepatocellular carcinoma in chronic carriers of hepatitis B virus: incidence and prevalence of hepatocellular carcinoma in a North American urban population. Hepatology 1995;22:432-8.

108. Okuda K, Ohtsuki T, Obata H, et al. Natural history of hepatocellular carcinoma and prognosis in relation to treatment. Study of 850 patients. Cancer 1985;56:918-28.

109. Heyward WL, Lanier AP, McMahon BJ, Fitzgerald MA, Kilkenny S, Paprocki TR. Early detection of primary hepatocellular carcinoma. Screening for primary hepatocellular carcinoma among persons infected with hepatitis B virus. JAMA 1985;254:3052-4.
110. Franks AL, Berg CJ, Kane MA, et al. Hepatitis B virus infection among children born in the United States to Southeast Asian refugees. N Engl J Med 1989;321:1301-5.

111. Hurie MB, Mast EE, Davis JP. Horizontal transmission of hepatitis B virus infection to United States-born children of Hmong refugees. Pediatrics 1992;89:269-73.

112. Mahoney FJ, Lawrence M, Scott C, Le Q, Lambert S, Farley TA. Continuing risk for hepatitis B virus transmission among Southeast Asian infants in Louisiana. Pediatrics 1995;96:1113-6.

113. Prevention of transmission of hepatitis B. Can Med Assoc J 1998;159:71-6.

114. Vento S, Garofano T, Renzini C, Cainelli F, Casali F, Ghironzi G. Fulminant hepatitis associated with hepatitis A virus superinfection in patients with chronic hepatitis C. N Engl J Med 1998;338:286-90.

115. Keeffe EB, Iwarson S, McMahon BJ, et al. Safety and immunogenicity of hepatitis $\mathrm{A}$ vaccine in patients with chronic liver disease. Hepatology $1998 ; 27: 881-6$

116. Preventing hepatitis A infections. National Advisory Committee on Immunization statement. Laboratory Centre for Disease Control. Can Fam Physician 1995;41:1222-8.

117. Linnen J, Wages J Jr, Zhang-Keck ZY, et al. Molecular cloning and disease association of hepatitis $G$ virus: a transfusion-transmissible agent. Science 1996;271:505-8

118. Alter HJ, Nakatsuji Y, Melpolder J, et al. The incidence of transfusion-associated hepatitis $\mathrm{G}$ virus infection and its relation to liver disease. N Engl J Med 1997;336:747-54.

119. Alter MJ, Gallagher M, Morris TT, et al. Acute non-A-E hepatitis in the United States and the role of hepatitis $G$ virus infection. Sentinel Counties Viral Hepatitis Study Team. N Engl J Med 1997;336:741-6.

120. Frider B, Sookoian S, Castano G, et al. Detection of hepatitis G virus RNA in patients with acute non-A-E hepatitis. J Viral Hepatol 1998;5:161-4.

121. Pessoa MG, Terrault NA, Detmer J, et al. Quantitation of hepatitis G and $\mathrm{C}$ viruses in the liver: evidence that hepatitis $\mathrm{G}$ virus is not hepatotropic. Hepatology 1998;27:877-80.

122. Berenguer M, Terrault NA, Piatak M, et al. Hepatitis G virus infection in patients with hepatitis $\mathrm{C}$ virus infection undergoing liver transplantation. Gastroenterology 1996;111:1569-75.

123. Naoumov NV, Petrova EP, Thomas MG, Williams R. Presence of a newly described human DNA virus (TTV) in patients with liver disease. Lancet 1998;352:195-7.

124. Simmonds P, Davidson F, Lycett C, et al. Detection of a novel DNA virus (TTV) in blood donors and blood products. Lancet 1998;352:191-5.

125. Hsieh Sy, Wu YH, Ho YP, Tsao KC, Yeh CT, Liaw YF. High prevalence of TT virus infection in healthy children and adults and in patients with liver disease in Taiwan. J Clin Microbiol 1999;37:1829-31. 


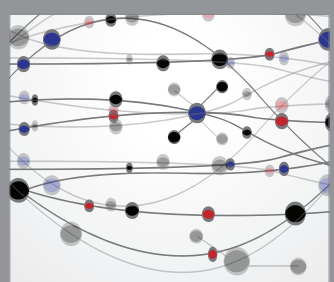

The Scientific World Journal
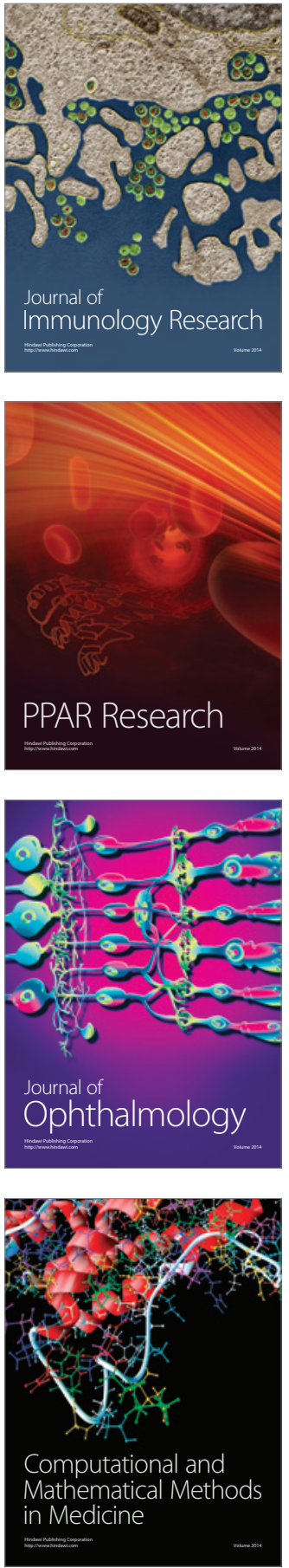

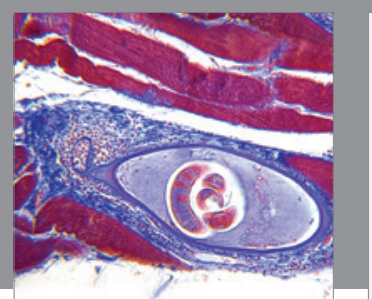

Gastroenterology Research and Practice

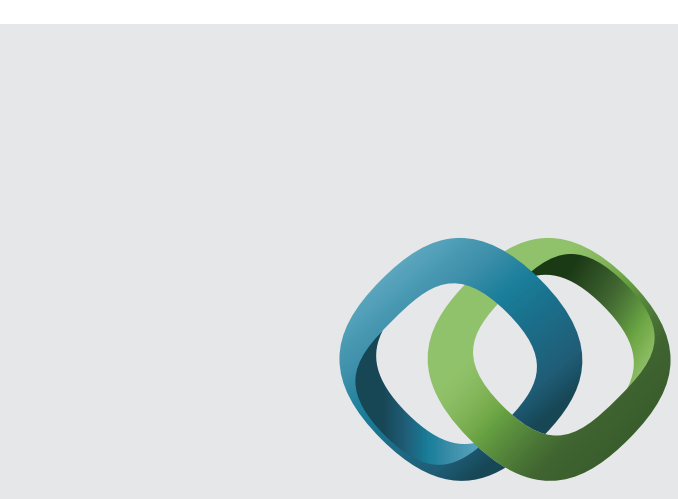

\section{Hindawi}

Submit your manuscripts at

http://www.hindawi.com
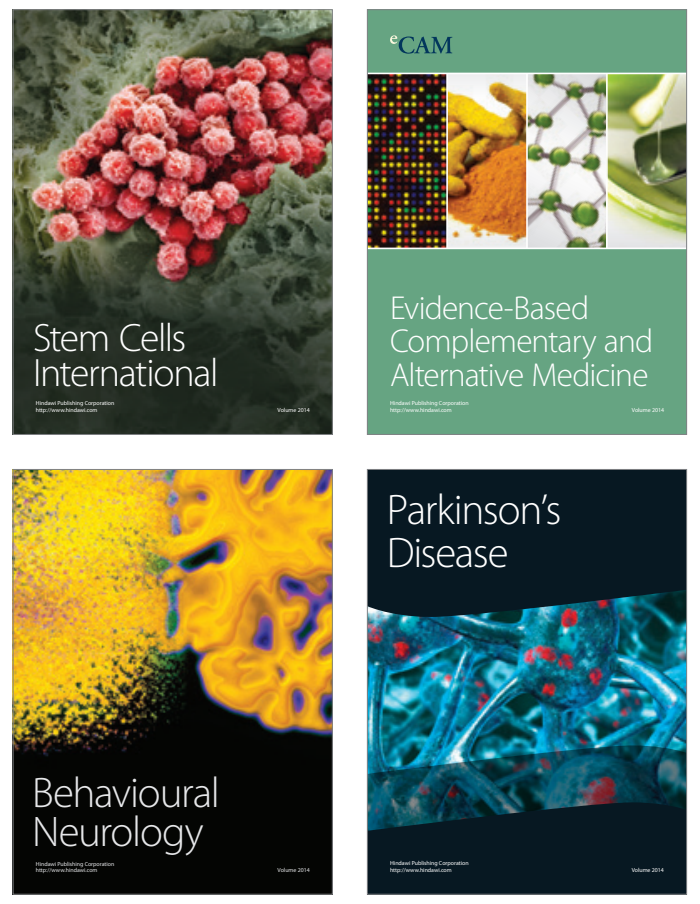
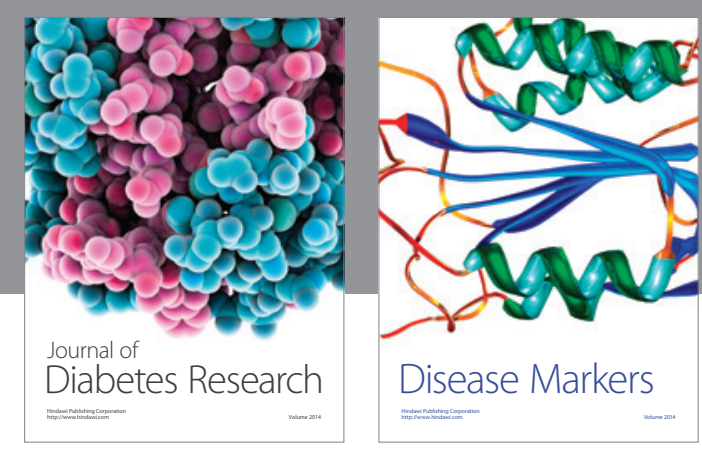

Disease Markers
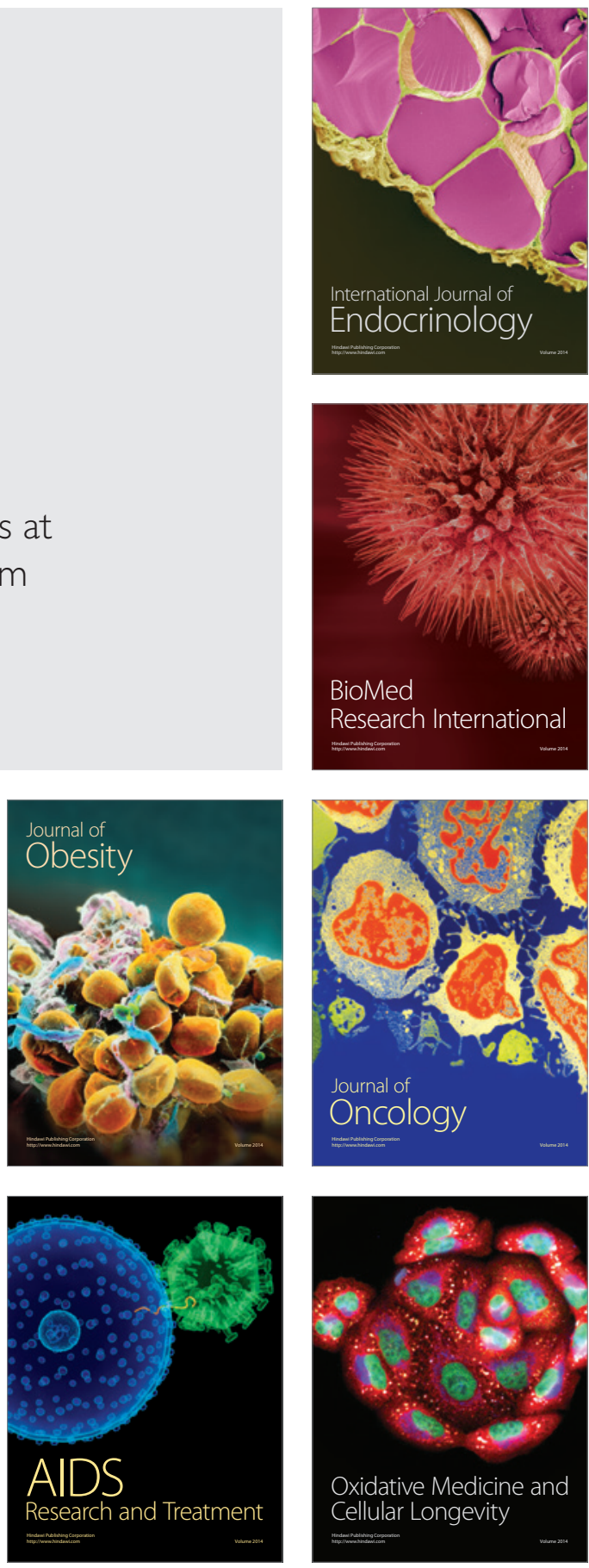